Article

\title{
The Noisy Counter-Revolution: Understanding the Cultural Conditions and Dynamics of Populist Politics in Europe in the Digital Age
}

\author{
Lars Rensmann \\ Centre for International Relations and Department of European Languages and Cultures, University of Groningen, 9712 EK \\ Groningen, The Netherlands; E-Mail: I.p.rensmann@rug.nl
}

Submitted: 7 August 2017 | Accepted: 15 November 2017 | Published: 29 December 2017

\begin{abstract}
The article argues for a cultural turn in the study of populist politics in Europe. Integrating insights from three fieldspolitical sociology, political psychology, and media studies-a new, multi-disciplinary framework is proposed to theorize particular cultural conditions favorable to the electoral success of populist parties. Through this lens, the fourth wave of populism should be viewed as a "noisy", anti-cosmopolitan counter-revolution in defense of traditional cultural identity. Reflective of a deep-seated, value-based great divide in European democracies that largely trumps economic cleavages, populist parties first and foremost politically mobilize long lingering cultural discontent and successfully express a backlash against cultural change. While the populist counter-revolution is engendered by profoundly transformed communicative conditions in the age of social media, its emotional force can best be theorized with the political psychology of authoritarianism: as a new type of authoritarian cultural revolt.
\end{abstract}

\section{Keywords}

anti-cosmopolitanism; authoritarianism; cultural turn; noisy counter-revolution; politics of transgression; populism; postfactual politics; social media

Issue

This article is part of the issue "Populism and the Remaking of (II)Liberal Democracy in Europe", edited by Lars Rensmann (University of Groningen, The Netherlands), Sarah L. de Lange (University of Amsterdam, The Netherlands) and Stefan Couperus (University of Groningen, The Netherlands).

(C) 2017 by the author; licensee Cogitatio (Lisbon, Portugal). This article is licensed under a Creative Commons Attribution 4.0 International License (CC BY).

\section{Introduction: Reframing Populist Politics within Liberal Democracies}

Populist actors have unsettled and begun reshaping European party systems and democracy. In recent election cycles, populist political parties like Fidesz-Hungarian Civic Alliance (since 2010) and the PiS (Law and Justice) in Poland consolidated or gained government positions in Eastern Europe. Following West European elections in 2017, the French Front National, the Dutch Partij Voor de Vrijheit (PVV) and the German Alternative für Deutschland (AfD)-the latter entering parliament for the first time and immediately becoming the third largest party-are now main opposition parties, challenging mainstream competitors but also the very framework of existing constitutional liberal democracies.
In response to their electoral performances and successes, illiberal populist actors are the subject of scholarly interest that is growing on an almost exponential scale. Yet, because such efforts are often confined to examining agents, political opportunity structures, voter preferences, and party system change, even innovative research exploring causal mechanisms may miss the scope and depth of cultural undercurrents driving populist success. This article suggests that the puzzling crossnational ascendancy of populist actors should be explored in the context of profound politico-cultural transformations and conflicts within liberal democracies. Opposing established parties in both their form and content, populist actors understand themselves as movementparties that primarily express-and often successfully appeal to-cultural discontent and identity concerns rather 
than proposing specific political or economic goals. Research thus needs to respond to this self-understanding reflected in parties and their voters (Taub, 2017), and theorize the broader underlying cultural conditions, conflicts, and dynamics at play in populist mobilizations.

The article argues for a "cultural turn" in the study of contemporary populist politics. In so doing, it advances a novel, expanded theoretical framework. It is based on three interlinked components and claims that integrate and build upon initial findings from three disciplinary perspectives hitherto underrepresented in research on populist politics in Europe: political sociology, political psychology, and media studies. Such an expanded view points to an interrelated set of theoretical arguments on broader cultural-specifically socio-cultural, politicopsychological, and communicative-conditions and dynamics we deem crucial for explaining the current success of populist actors. The goal of this article is to bring these perspectives into substantive conversation, and to initiate a multi-disciplinary theoretical reframing for the study of contemporary populism that expands political science research by integrating insights from the respective fields. Such a multi-disciplinary, theoryguided perspective on populist politics in the context of politico-cultural and societal undercurrents takes inspiration from Frankfurt School critical theory, and especially their studies on authoritarianism, identity, and the communication of prejudice. Their theoretical models focus on illuminating the societal reproduction of persistent streaks of authoritarianism within the political cultures of political modernity which are mobilized time and again and recurringly challenge the boundaries of modern constitutional democracies (Rensmann, 2017). ${ }^{1}$

Substantively, this article thereby aims to conceptualize the populist phenomenon as an authoritariannativist cultural counter-revolution, as well as to theorize both transformed and persistent politico-cultural origins of the recent electoral boost of populist parties. The theoretical argument is three-fold: first, it is suggested that populists can benefit from and mobilize a no longer "silent" counter-revolution (Ignazi, 1992, 2003). The populists' appeal is primarily cultural: it thrives on a long lingering, increasingly polarized "great divide", or clash within civilizations, based on social value and cultural identity conflicts in post-industrial European societies. This divide is arguably more profound than political sociologists assume, who rightly diagnose a socio-cultural backlash (Alexander \& Welzel, 2017; Inglehart \& Norris, 2016).

Second, the cultural counter-revolution is theorized by employing new and classical authoritarianism theory, especially political-psychological models of authoritarian rebellion (Adorno, Frenkel-Brunswik, Levinson, \& Sanford, 1950). The "noisy" counter-revolution is conceived as a transgressive, authoritarian revolt directed against liberal-cosmopolitan socio-cultural transformations and culturally inclusive identities in globalized immigration societies-and against immigrants and "the elite" identified with those changes.

Third, theorizing initial findings from media studies, it is argued that the new social media culture and its disintermediated political communication patterns have helped erode boundaries of civil and factual discourse in political culture, propelling populist actors, their claims, and their authoritarian politics of transgression against norms of liberal democracy.

After reconceptualizing the ideological core of European populist movement-parties, each of the three proposed arguments about cultural conditions for the electoral success of populist politics is subsequently unpacked and molded into substantiated, interrelated theoretical claims. In so doing, the article points to an integrated new framework preparing a cultural turn in the study of populism in Europe. Rather then isolating or operationalizing specific hypotheses and testing them, initial research from three bodies of disciplinary literature is critically synthesized to advance a novel cultural perspective and lay out potential lines for future inquiry.

\section{Parties and Movements: Reconceptualizing Populist Actors and their Cultural Appeal}

Research has demonstrated that "populism" is well suited to understanding key features of the most significant movement-parties challenging European party systems today (Mudde, 2005, 2007; Müller, 2016; Rensmann, 2006). Yet, conceptualizations of electorally relevant European populist parties need to pay more attention to the cultural core of their ideological appeal: First and foremost, European populist parties-left and right-express and articulate cultural discontent and particular(istic) notions of cultural identity, a widely shared feeling of unease with globalized immigration societies and their elites, rather than specific political goals or a coherent ideology. These parties, it is argued here, ideologically point to a cultural counter-revolution (Ignazi, 2003) against established politics and society as much as a political one. A re-conceptualization of their ideological core should build on previous ideational definitions, but needs to further elaborate their cultural appeal, commonly categorized as authoritarian and nativist.

Following Cas Mudde (2005, 2007), populism functions as a "thin-centered ideology" that almost always appears attached to other ideological traits. Populism is marked by constructing stark group dichotomies: It considers society as separated into two antagonistic camps, "the (pure) people" versus "the (corrupt) elite", while the latter allegedly victimizes the former (Mudde \& Rovira Kaltwasser, 2017, p. 6). Often employing a specific "image of the vox populi" as a particular, sharply demar-

\footnotetext{
${ }^{1}$ The proposed new framework advancing a 'cultural turn' in populism studies also builds on my previous research into the emergence and political potential of the socio-cultural divide currently reshaping party politics in liberal democracies. Populist politics often failed only because of leadership failures and organizational factors, not because of a lack of politico-cultural potential (Rensmann, 2006, 2011, 2012).
} 
cated, homogenous identity, populists argue that democracy should be a direct expression of a presumed "general will" (Mudde \& Rovira Kaltwasser, 2017, p. 20). Thus populism implies a distinct ideological contrast to pluralism; and, we would add, to liberal constitutionalism with its universalistic underpinnings, focus on separation of powers, and individual civil rights.

While this ideological profile can apply to a variety of political actors, movements or parties, it is not grasped in formal conceptualizations of populism as a specific type of mobilization, leadership style, or discursive strategy (Mudde \& Rovira Kaltwasser, 2017, p. 19). The constructed vertical dichotomy between "the corrupt elite" and "the pure people", which can be seen as populism's core feature, may also appear in mainstream politics. For actors and parties which can be classified as populist, this binary anti-elitism, or anti-pluralist dichotomy, is a constitutive part of their ideology. Yet the implicitly antiuniversalistic, anti-pluralistic notion of "the good people" as an homogenous identity also automatically carries cultural weight that is overlooked by Mudde and Rovira Kaltwasser: it presupposes the defense of cultural identity, and appeals to cultural discontent with perceived liberal rule. This includes "left" populist movement-parties like La France Insoumise led by former socialist Jean-Luc Mélenchon, who opposes refugees and reiterated Marine Le Pen's claim that the French nation shares no responsibility for the Vichy regime's crimes (Haaretz, 2017). ${ }^{2}$

Linked to this not quite as "thin" but implicitly culturally charged ideological center, most European populist parties also employ a second, horizontal dichotomy that is heavily culturally biased-an antagonism of "us" versus "the others", the "nation" against minorities, (im)migrants, refugees, Muslims, Jews, and "foreign powers" (Greven, 2016; Rensmann, 2006). Distinctively nativist (Mudde, 2007), they employ a specific, exclusionary conception of the people as a culturally or ethnically homogenous nation that is contrasted to antagonistic, demonized outgroups (Greven, 2016, p. 5). Whoever is construed as not "truly" belonging to "the people" is blamed for its problems, if not viewed as an "enemy of the people". While often migrants are targeted, those constructed as "others" can vary. All populist actors have attacked the "globalist elite" and supported some level of national economic protectionism, traditionally associated with "the left" (Kriesi, 2014; Rensmann, 2011). Our reconceptualization of populist parties takes into account that this overtly cultural, horizontal dichotomy between "the good people" and nonnative outgroups representing globalization is not limited to right-wing populists. Neither are conspiratorial views of globalization as a zero-sum game favoring "the global elite" and rendering "the people" as losers. In fact, distinctions between left and right populism based on the criterion nativism vs. cosmopolitanism are complicated and difficult to empirically substantiate, at least in the European context. Several left-wing populists in Europe, from the German Left Party to La France Insoumise, share nativist, anti-cosmopolitan sentiments, advocate national protectionism, and target presumably all-powerful external global forces for victimizing "the nation" (Hartleb, 2017). ${ }^{3}$

Further complicating traditional left/right divides, authoritarian features constitute a third ideological trait displayed among most populist actors today (Mudde, 2007). Negative political communication (Greven, 2016, p. 1) and apocalyptic crisis discourses, characteristic for populists from the Movimento Cinque Stelle to the AfD (Decker, 2016), are linked to calls for authoritarian solutions. Authoritarianism as an ideological feature-in contrast to political-psychological explanatory models, to which we turn later-is hereby understood as support for illiberal, top-down decision-making allowing for measures such as suspending the rule of law or constitutional rights, democratic deliberation, liberal procedural norms, and institutionalized separation of powers. The common support for authoritarianism has an affinity to the populists' anti-pluralistic, homogenized, culturally biased concept of "the people", as they claim to represent "the people themselves", understood as a symbolic, fictional body constituted "outside existing democratic procedures" (Müller, 2016, p. 27). To be sure, seeking to mobilize bottom-up "movements" and "culture" against an allegedly "broken" liberal government rather than aiming to govern lawful institutions, European populists thereby do not fashion themselves as regular electoral competitors, but as agents of "true" or "illiberal democracy" (Viktor Orbán). This may entail granting unrestricted authority to a leader articulating unfiltered sentiments of an imagined vox populi, by virtue of a certain culture or group membership, or the ratification of illiberal political measures by referenda that suggest direct democratic mandates (Müller, 2016, p. 29).

Integrating Mudde's ideational definition as a thincentered ideology based on an "elite-people" dichotomy, the proposed re-conceptualization of contemporary European populist actors, parties, and movements views cultural underpinnings as crucial to understand populist ideology and appeal: cultural bias, identity, and sentiments are a constitutive ideological undercurrent. ${ }^{4}$ It largely suspends left-right distinctionsdespite their ongoing relevance in self-understandings of different political milieus, and notwithstanding some

\footnotetext{
2 The case of Mélenchon shows that both anti-immigrant rhetoric and the revisionist downplaying of a national past tainted by Nazi crimes and collaborations (in order to absolve "the people" from criminal responsibility and to advance national myth-making) are not exclusive features of the radical right.

${ }^{3}$ Only Greek Syriza and the Spanish Podemos decidedly support immigration, and only the latter opposes Euro-scepticism, which cuts across left-right divides (Teperoglou \& Tsatsanis, 2011).

${ }^{4}$ Hans-Georg Betz observed an "identitarian turn" and respective programmatic convergences of populist parties in the 1990s, if programmatic contrasts among them were ever that stark as some early country-specific studies of opportunity sturctures had suggested (Betz, 2004; Bornschier, 2010b, p. 3).
} 
policy differences. ${ }^{5}$ Despite their cross-national distinctions, however, all "right-wing" and most "left-wing" populist actors share key common ideological denominators shaped by authoritarianism, anti-liberal, antipluralistic vertical and horizontal dichotomies, which implicitly or explicitly endorse cultural exclusivity, identity, and denigration of "others". Conceptualizing European populist parties this way, they can be understood as political articulations and mobilizations of an illiberal, culturally charged authoritarian-nativist counter-revolution against liberal democracy, inclusive cultural diversity, and cosmopolitan social value change. ${ }^{6}$

\section{A Silent Counter-Revolution Turned Noisy: Populist Contestations of Cosmopolitan Value Change as Expressions of a Socio-Cultural Divide}

To better explain the origins and appeal of this politicocultural counter-revolution ideologically mobilized by populist parties, it should be framed in the context of a socio-cultural "great divide" restructuring political competition in European democracies. The populist resurgence, it is argued here, points to deep-seated and now salient cultural conflicts on collective identity and societal values within society that have previously been underestimated in empirical research and theoretical models.

Structural/institutional approaches examining electoral market competition and the erosion of "frozen" party systems help address improved political opportunity structures for newcomers in light of shrinking support for catch-all parties, especially on the center-left. Yet they largely fail to grasp the specific causes that benefit populist parties especially, as they pay too little attention to ideological content. Why don't they favor green, antiauthoritarian, or new socialist parties (Kriesi, 2014; Muis \& Immerzeel, 2017)? Agency-centered supply-side approaches, which focus on party organization, agent strategy, and platform modernizations-or the lack thereofare good at explaining cross-national variation and volatility (Art, 2011; Mudde, 2007; Rensmann, 2012), yet add little to explain the largely synchronous success of "fourth wave" populism (Mudde, 2013).

Demographic demand-side explanations face limitations because support for populist actors tends to cut across various groups, although there are some rele- vant correlations. Male support for authoritarian populist parties is generally stronger-according to research by Forschungsgruppe Wahlen, the AfD received $16 \%$ of the male but only $9 \%$ of the female vote (2017 overall: $12.6 \%$ ). While there is little variation between young and old voters, the AfD (and other populist parties) is doing slightly better among middle aged groups (Naumann, 2017). ${ }^{7}$ The most reliable demographic predictor is education. Populist parties tend to do better among voters with low levels of education. A striking example is the French Front National, supported by up to $50 \%$ of likely voters without high school degree, in contrast to $16 \%$ with academic degree (Les Echos, 2015).

Explanations that focus on economic factors (relative social deprivation, unemployment, and economic crisis, etc.) largely fall short of yielding robust findings without accounting for a variety of contextual and other factors (Arzheimer, 2009). Guiso, Herrera and Morelli (2017) suggest economic security directly affects intentions to vote for populist parties, though this is mitigated by economic shocks, which tend to discourage actual voter turn-out. Koen Damhuis's study of PVV voters (2017) confirms that they include a broad spectrum of social strata. Hence, the AfD is almost equally supported by all social strata - with the exception, however, of blue-collar workers, $19 \%$ of whom voted for the populist party (compared to $12.6 \%$ overall). ${ }^{8}$ Mirroring the results of the Frankfurt School's research on likely fascist voters in the 1920s, some (though not all) studies also show that populist support tends to be disproportionately high among small business owners and blue-collar workers, or economic "globalization losers" (Kriesi et al., 2006). Be that as it may, there are few indicators that such relative working class support is based on economic issues-even though neo-liberal austerity policies affect workers.

Rather, evidence from AfD voters indicates that cultural issues-the protection of national cultural identity, allegedly threatened by (Muslim) immigrants and the influx of refugees, opposition to "cosmopolitan" elite culture, and the rejection of progressive social value change - are salient among all AfD supporters (Taub, 2017). Only $14 \%$ of AfD voters prefer Germany to be an open-minded, cosmopolitan country, in contrast to the majority among voters of other parties (Naumann, 2017)..$^{9}$ Anti-cosmopotitan, authoritarian-nativist cultural attitudes are by

\footnotetext{
${ }^{5}$ While radical right and left are still relevant analytical categories, the new patterns point to constitutive similarities among populist parties, rendering these distinctions less relevant in view of ideological features, platforms, and voters. Mudde and Rovira Kaltwasser's distinctions between "exclusionary" versus "inclusionary" populism (2013) may be more useful, though most populist parties in Europe are not inclusionary. When analyzing particularismuniversalism, nationalism-cosmopolitanism, authoritarianism-liberalism divides, most populist parties, "left" and "right", are today linked to the first side of these divisions, opposing, in the words of left-wing Brexit supporter Alan Johnson, the "Davos man" and "the globalist elite" (Johnson, 2017).

6 Jeremy Corbyn's attempt to transform the British Labor Party, traditionally center-left, into a populist movement-party (with the support of "Momentum", a movement-organization within the party founded in 2015), is a case in point. He does not just consistently employ populist vertical anti-elite dichotomies ("the many" versus "the few") but also horizontal dichotomies (e.g. blaming the EU for British neo-liberal policy and supporting anti-immigrant policy to allegedly protect domestic wages; Chakelian, 2017). He also has a decidedly authoritarian streak, displayed in support for authoritarian regimes in Venezuela, Iran and Russia and violent groups like Hamas, Hezbollah and the IRA (Hirsh, 2017).

${ }^{7}$ An outlier is France: Only $20 \%$ of voters over 65 , but $44 \%$ of 18 to 24 -year-olds backed Front National leader Le Pen in the second round of the presidential election (Kentish, 2017). The data on the AfD are based on a combination of a telephone survey among 1,666 randomly selected eligible voters one week before the 2017 national parliamentary election, and of a survey of 41,334 voters on the day of the election, both conducted by Forschungsgruppe Wahlen. The French data are based on a survey among 2,797 eligible voters, conducted by IFOP in March 2015.

${ }^{8}$ On the survey data see footnote 7

${ }^{9}$ See footnote 7 .
} 
far the most reliable predictors of populist voting. This is why political sociology that explores the evolution of conflicts on cultural values and identities offers the most promising direction to theorize populist success.

Four decades ago, Ronald Inglehart observed a "silent revolution" of post-material social value change as an effect of economic modernization and stability (Inglehart, 1977). Overall, cultural change has further progressed towards the increased acceptance of inclusive liberal-cosmopolitan and individual self-expression values (Inglehart \& Welzel, 2005), particularly striking among younger generational cohorts in increasingly culturally diversified, post-industrial democracies (Inglehart $\&$ Norris, 2009). The social value revolution eventually resonated in platforms and policies of mainstream parties (even if to varying degrees cross-nationally), leading to a recently accelerated cultural "cosmopolitanization of European party politics" (Rensmann, 2014).

Yet this cultural change has not been uncontested. Following the initial rise of "post-material" left and green parties representing social value change, Piero Ignazi suggests a wave of radical right success in the 1980s and 1990s benefited from a "silent counter-revolution" (1992, 2003), understood as a cultural backlash against social value change and demographic shifts related to immigration. Although it often became politically manifest only in short-lived protest votes and fluctuating performances of radical right populist parties, the societal undercurrent of the cultural counter-revolution has lingered on. Rather than disappearing, it has now fully translated from silent value opposition among relevant segments of voters and non-voters into robust support of outspoken, politically and electorally relevant movement-parties.

Indeed, new research indicates that the backlash stabilized and helped polarize political conflict along an increasingly salient great cultural divide within European democracies: a divide between liberal-cosmopolitan and authoritarian-nativist social values, or cosmopolitanism vs. nationalism, which largely trumps socio-economic cleavages (Bornschier, 2010a; Inglehart \& Norris, 2016; Kaldor, 1997; Rensmann, 2011). ${ }^{10}$ Inglehart and Norris demonstrate that populist support is primarily driven by once culturally predominant groups' cultural backlash against progressive social value change, or the displacement of traditional cultural norms and privileges (Inglehart \& Norris, 2016, p. 3). The authors use expert surveys of the 2014 Chapel Hill Expert Survey (CHES) to identify the ideological location of 268 political parties in 31 European countries and combine these data with national-level European party competition and the European Social Survey (2002-2014) to examine the crossnational evidence at individual level for the impact of the economic insecurity and cultural values as predictors of voting for populist parties. While the economic security theory, which views changes in the workforce in post-industrial economies responsible for populist parties' rise, gets inconsistent support, they find consistent evidence for the cultural backlash theory. Rising levels of economic insecurity may have their share. Yet, populist parties' rise above all reflect "a reaction against a wide range of rapid cultural changes that seem to be eroding the basic values and customs of Western societies" (Inglehart \& Norris, 2016, p. 30).

While offering an important empirical account of the cultural backlash, the authors fall short of further theorizing its causes beyond suggesting that rapid cultural change "catalyzed culture wars" (Inglehart \& Norris, 2016). Within the context of modernization theory, the backlash may then appear as a transitory phenomenon, a temporary "bump in the road" of socio-cultural modernization expressed by what Inglehart and Norris see to be an ethnocentric, partly aging white cultural minorityrather than conceiving the backlash in the context of reproduction of stable, resilient authoritarian legacies and cultural undercurrents within liberal democracies. A critical cultural theorizing of their empirical findings would also have to thoroughly reflect on underlying socio-economic origins facilitating wishes for cultural closure and exclusive identity-such as a structural crisis of global capitalist economic modernization that may undermine further socio-cultural modernization and democratization. ${ }^{11}$ Finally, the authors say little about the depth of the divide fueling cultural value and identity conflicts, and authoritarian populist challenges to liberal democracy, which seems to currently have lost some of its cultural appeal. ${ }^{12}$

Indeed, the forceful, noisy cultural counter-revolution seems to correlate with eroding trust in democratic institutions and laws, and declining support for liberal democracy. Roberto Stefan Foa and Yascha Mounk view an increasingly large pool for authoritarian populists as a sign of "democratic deconsolidation" (Foa \& Mounk, 2016). ${ }^{13}$ They suggest, contrary to Inglehart and Norris, that such disaffection with liberal democracy (and its culture) especially affects the youngest generational cohorts. While, for instance, $55 \%$ of Dutch citizens born before WWII accredited maximum importance to living in a democracy, only one in three millennials do so (Foa \& Mounk, 2016, pp. 7f.).

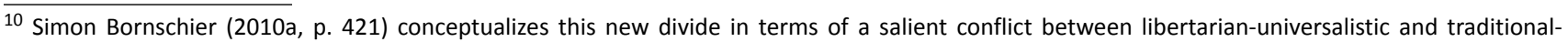
communitarian values.

11 To be sure, the authors call for additional robustness tests (Inglehart \& Norris, 2016, p. 30). And they concede that the cultural backlash may also be stimulated by heightened economic insecurity evoked by globalized market capitalism and its crises. Such interactive effects possibly make distinctions between economic insecurity and cultural backlash somewhat artificial (Inglehart \& Norris, 2016, p. 3).

12 Political psychologists Sniderman and Hagendoorn argue that rigid identity politics contributed to a "cultural conflict zone" in the Netherlands. They point to actual collisions of ways of lives, norms, and values within immigrant societies (Sniderman \& Hagendoorn, 2007).

${ }^{13}$ For a challenge on empirical grounds, see: Alexander \& Welzel (2017); Norris (2017); Voeten (2017).
} 


\section{An Authoritarian Cultural Revolt? Explaining the Populist Counter-Revolution in Context of the Political Psychology of Authoritarianism}

These empirical observations still leave much to be explained in terms of the underlying causes of the salient cultural divide, and the genesis of the politico-cultural backlash today. Which theoretical framework best explains the diagnosed noisy cultural counter-revolution, and the accelerated momentum of today's populist politicization of cultural identity and value change? We believe theorizing and research on the political psychology of authoritarianism, long ignored in studies on European populism, can partly help fill this theoretical and empirical void.

Matthew MacWilliams demonstrates that only one trait predicts if you are a Trump supporter. According to MacWilliams, this is not class, race, or age but authoritarianism. It is measured by responses to 4 questions pertaining to child-bearing: whether it is "more important for the voter to have a child who is respectful or independent; obedient or self-reliant; well-behaved or considerate; and well-mannered or curious" (MacWilliams, 2016). A study by political psychologist Pettigrew (2017) adds social dominance and prejudice to authoritarianism as constitutive for populist support. One initial, groundbreaking work by Hetherington and Weiler traces the recent political polarization in American politics to authoritarianism as an "attractive" explanatory framework (Hetherington $\&$ Weiler, 2009, p. 4). According to the authors, negative views on issues like immigration and the use of force reflect individual levels of authoritarianism and have gained salience through political decisions. However, while this important study contributes to a promising, theoretically grounded understanding of politico-cultural polarization paving the way for populist politics, it does not engage with populism, let alone populism in Europe. Moreover, it draws major inspiration from Adorno and the Frankfurt School (Hetherington \& Weiler, 2009, pp. 33-58), yet it does not fully engage with their critical-theoretical framework explaining political-psychological dispositions and dynamics of authoritarian politics.

Turning to the Frankfurt School's older research on the political psychology of authoritarianism, the populist surge in Europe can be theorized as an authoritarian cultural revolt. Authoritarianism is hereby understood not just as an ideological feature of populist parties or attitude among their voters, but also as a multi-faceted political-psychological binding "glue" unleashed in political group dynamics. ${ }^{14}$ Absorbing Frankfurt School theory, the origins and interactive dynamics at play that fuel the noisy counter-revolution point to a politically instigated collective rebellion, supported by aggregate indi- vidual attitudes and psychological dispositions, against post-industrial liberal democracy and its universalistic, inclusive, and non-authoritarian cultural underpinnings. Such revolt may benefit from economic insecurity of voters and a crisis of legitimacy of established parties and government, but cannot be reduced to either.

Adorno points to models of politically mobilized, collectively amplified psychological discontent. Adorno's theory of the "authoritarian" or "anti-democratic" syndrome refers to a psychological disposition linking desires for both authoritarian submission and aggression to anti-egalitarian ideologies (e.g. antisemitism, nationalism, and sexism; Adorno et al., 1950; for a thorough discussion, see Rensmann, 2017). This syndrome translates into susceptibility to fantasies of persecution and conspiracy myths personifying social problems; binary thinking attributing all personal or societal problems to alleged "enemies", in sharp contrast to narcissistic gains through collective self-aggrandizement of one's own group and "cultural identity"; and projections on perceived "others" of fantasies, anxieties, and social transgressions otherwise taboo (e.g. viewing immigrants as rapists)-all of which can be detected in current populist mobilizations and their self-reinforcing performative dynamics (Rensmann, 2017, pp. 321-357; Wodak, 2015, p. 154).

Explaining the appeal of authoritarian-nativist demagogues we find mirrored in today's populists, Adorno theorizes these dispositions in the context of a culturally wide-spread ego weakness present even in consolidated modern democratic cultures. He views it as being the product of structural insecurity, social dependence, and economic pressure experienced by many individuals in modern societies, which are shaped by abstract forms of societal domination and forceful socio-economic imperatives (Rensmann, 2017, pp. 215-230). According to Adorno, these socio-cultural conditions engender feelings of cultural alienation and reified, stereotypical perceptions of the social world manifest in the authoritarian syndrome. It implies submissiveness and aggression: longing for subordinating under a strong, idealized collective and authority figure alongside the denigration of constructed "enemies" of the (national) group, as well as the urge to break free from civil rules without breaking with the social order. According to Adorno's theory of authoritarian rebellion (Rensmann, 2017, pp. 127-132), populists may offer exactly these particular, tribalistic and aggressive forms of emotional gratification and psychological bonding that authoritarian subjects and milieus look for, rather than economic gains: Releasing verbal authoritarian aggression by lashing out against those seen as "different", "alien", "weak" or "dangerous" others (all present in the imagery portraying refugees), while

\footnotetext{
${ }^{14}$ A recent exploratory study by Rooduijn (2014) on Dutch voters confirms that authoritarianism is part of the attitudinal complex of radical right populist voters, but does not employ authoritarianism as an explanatory theoretical framework.
} 
promising to restore forceful sanctioning authority and elevate the in-group, "the good people", by bringing back past national collective glory and pride. ${ }^{15}$

Such critical theorizing of the populist surge as an authoritarian cultural revolt against the alleged cultural weakness of liberal democracy may help understand the admiration for Putin's autocratic leadership in Russia by both populist voters and parties like the AfD or Front National. It may also help explain why provocative violations of civil liberal norms, discursive boundaries, and even legal ones by populists-their willingness to break the rules and cultural taboos-do not seem to alienate but rather attract populist core voters, as a study of Trump loyalists shows (Carter \& Johnston Conover, 2017). Benjamin Moffitt and Simon Tormey understand this "coarsening of political discourse" in disregard of "appropriate' ways of acting in the political realm" as a core element of what they conceptualize as "populist political style" (Moffitt \& Tormey, 2014, p. 392). Constantly challenging the public "boundaries of the speakable" (Rensmann, 2006), the dynamics of a new type of disruptive politics of transgression have already transformed political cultures. For instance, the Dutch populist Wilders provoked a ruling by a regional court that found him guilty of inflammatory speech against Muslims, only to enjoy media attention for blaming the legal system and lamenting infringement of free speech (Adam, 2016). In reference to chancellor Merkel, AfD politicians proclaim "We'll lock up the old bitch", expressing vulgar authoritarian punishment fantasies against a denigrated political elite and migrants.

Seen in this theoretical framework, the current immigration crisis which has coincided with populist electoral gains is less a cause for successful populist mobilization than an opportunity for politically unleashing existing authoritarian dispositions and anti-cosmopolitan cultural identity constructs among significant milieus. Since 2015, the European refugee crisis in the wake of the civil war in Syria helped further boost the authoritarian-nativist cultural backlash, and publicly transform it into a noisy political rebellion. This is especially the case in countries like Germany, where many migrants were able to find refuge (Ostrand, 2015). ${ }^{16}$ However, European surveys that include countries hardly affected by the refugee crisis, such as Poland or the UK (Ostrand, 2015, p. 273), also show wide-spread opposition to new migration. In a recent
PEW survey in 10 major European countries, 59\% of respondents are concerned that the influx of refugees "will increase the threat of domestic terrorism", with majorities holding this view in 8 of 10 countries. Strikingly, only a minority thinks that "growing diversity makes the country a better place to live", including such culturally diverse countries like the Netherlands (17\%), the UK (33\%), and France (26\%) (Poushter, 2016).

Even though mass immigration matters, problems with politico-cultural inclusion exist, and the threat from Islamist terrorism is a serious policy issue, these crossnational data indicate that underlying, authoritariannativist cultural perceptions play a major role, partly independent of actual migration numbers and the presence of (Muslim) immigrants. Following our argument, these data can serve as indicators of an affectively charged politico-cultural divide in society on issues of collective identity, diversity, and cosmopolitan social value change-by now largely overshadowing other cleavages among voters-and a consolidated, proliferating culture of authoritarian aggressions and transgressions expressed by populist actors and other counterrevolutionary groups on squares, demonstrations, and social media. Indeed, the authoritarian backlash today in defense of a particular, exclusive conception of national cultural identity is often articulated with regard to fear of an increasing influence of Muslims and Islamand at times in apocalyptic terms. The populist wish to "restore" a pure, ethnic national identity and to "take back our country and Volk" (as cited in Cohen, 2017) is thereby frequently linked to calls for "de-Islamization" (Geert Wilders, as cited in Cannane, 2017)-if need be by authoritarian measures. "Globalist" Jews also often serve as imagined subversive "enemies" of cultural identity; occasionally they are construed as string-pullers behind Muslim migration-the authoritarian populist prime minister of Hungary makes this claim against the Jewish billionaire George Soros (Gorondi, 2017; see also Rensmann, 2011). ${ }^{17}$

\section{Reconfigured Political Conflict in the Digital Age: Post-Factual Transgressions on Social Media as Cultural Facilitators of Populist Politics}

The question about changing cultural conditions favorable for authoritarian populist mobilizations points to an-

\footnotetext{
15 Authoritarianism as an explanatory framework for populist success seems especially useful in view of the disproportionate success of populist parties in post-authoritarian, post-Communist contexts, like PiS in Poland, Fidesz in Hungary. In the 2017 elections the AfD became the strongest party in Saxony and generally considerably more electorally successful in former East Germany (21.5\%), still shaped by authoritarian cultural legacies, than in former West Germany.

16 In the 2017 elections, for instance, the new German populist party AfD gained massively among former non-voters across the country, and especially in authoritarian-nativist strongholds in East Germany still marred by authoritarian, anti-democratic legacies. But it also collected large shares in some West German towns locally dealing with the refugee crisis, where refugees became the no. 1 topic-such as Deggendorf in Bavaria, where $31.5 \%$ voted for the right-wing populists (Osel, 2017).

17 It is noteworthy that there is some variation in the rhetoric mobilized by European populist parties on Islam. Some actors, like Geert Wilders, claim that they in fact protect European liberal values and gender equality against an illiberal Islam (Zúquete, 2008). Rogers Brubaker calls this "civilizationism" (Brubaker, 2017). Yet such seemingly pro-liberal defenses of liberal-egalitarian norms are deceptive insofar as they are regularly intermingled with ethnicized myths of cultural superiority and inferiority, and accompanied by racialized stereotypes of Muslims as essentially "culturally incompatible" with European societies-labeling Muslims collectively as dangerous extremists or as rapists. This betrays the grounding of such populist rhetoric in the authoritarian, anti-liberal and anti-cosmoplitan side of the cultural divide, rather than being an expression of a liberal-secular critique of political Islam(ism).
} 
other interrelated field of inquiry beyond conventional frameworks for the study of party politics. Findings from political sociology on the cultural appeal of a counterrevolutionary backlash mobilized by populists should not only be linked to research on the political psychology of authoritarianism to better theorize the scope and depth of this appeal. Understanding the transformed environment engendering, reinforcing and polarizing the divide on social values and cultural identity also means paying attention to the role of social media and digital publics. It requires theoretically and empirically integrating research from media studies on changed communicative conditions of politics. Arguments on the relevance of social media bubbles and fake news disseminated through new digital media have gained prominence in recent debates about populism. But these arguments have yet to resonate in broader systematic research on this link. While the precise relations of populist communication and social media have hardly been researched yet, first quantitative studies of populist communication strategies show that populist parties make disproportionate use of Facebook and Twitter (Ernst, Engesser, Büchel, Blassnig, \& Esser, 2017; on initial work on populism and new media see Coretti \& Pica, 2015; Mazzoleni, 2008; Reinemann, Aalberg, Esser, Strömbäck, \& de Vreese, 2017; Wirth et al., 2016).

Three initial insights from research on the implications of new digital media on conditions of political communication seem particularly relevant for both reframing the study of populism and theorizing the profoundly changed cultural conditions for its impact: First, disintermediating technologies like Facebook and Twitter increasingly replace newspapers and other media serving as intermediaries between politics and citizens. This transforms patterns of political interaction and publicity in multiple ways. Social media can have democratizing effects on public discourse because they engender immediate fact-checking by civil society actors, increasing the political accountability of those who hold public office. Social media also "have the potential to favor citizens' activism", enable regular citizens to actively participate in public debates and offer "free networked space" for and between political actors and non-actors (Ceron, 2017, pp. $179,197 f$.). Yet studies have shown that social media can also, at least for ideologically and culturally predisposed groups and audiences, generate non-pluralistic arenas: self-referential and segregated publics in which particular world-views are affirmed and reinforced. Rather than facilitating rational deliberation about policies across a large public spectrum, social media can have constraining ideological effects and limit genuine debate between competing views; favorable to populist rhetoric, which is shaped by constructed group dichotomies, communication tends to be shaped by fragmentation and polarization (Ceron, 2017, p. 198). Digital media may thus add to centrifugal tendencies of polarization in political lifeand the breakdown of the public into fragmented, nonpluralistic, and biased micro-publics warped in closed world-views. ${ }^{18}$

Second, recent communication studies show that the rhetorics of horizontalism regarding social media platforms often hide vertical structures and inequalities. This has been demonstrated in the case of the Italian populist movement-party Movimento Cinque Stelle led by Beppe Grillo. While glorifying social media technology, it masks authoritarian, intransparent techniques (Coretti, 2014). Moreover, both Facebook and Google have boosted, arguably involuntarily, fake news sites in the past, including prominently Sputnik and Russia Today, which spread disinformation in the service of the authoritarian Russian government. Communications scholars have analyzed intransparencies, including algorithms subject to manipulation (Coretti \& Pica, 2015, p. 316; Treré \& Barassi, 2015, p. 299). There is mounting evidence that Russia, in addition to overt support for European populists, used cyberwar techniques on social media, interfering with fake news and "bots" (fake automatized accounts) on Twitter and Facebook on behalf of populist electoral campaigns in America, France, and Germany-with the presumed goal of destabilizing democracies (Röpcke, 2017; Rotella, 2017; Shane, 2017).

Third, Dahlgren (2005) observed already more than a decade ago negative effects of new digital media on civic cultural norms, alongside effects of transnational critical publicity. Recent studies validate the claim that especially social media discourses have engendered the growth of unfiltered hate speech and verbal violence, as well as post-factual claims and conspiracy myths both from below, or bottom up, and top down from sponsored (fake) news sites-often articulated anonymously and spreading instantaneously (Ceron, 2017, p. 1). Circumventing traditional media and their discursive filters, both social media and populist politics boost the politics of transgression (see Reinemann et al., 2017)-the latter often with the help of social media, as a study by Krämer (2017) on populist online practices shows. In addition to evading established media and developing a populist identity and ideology, main functions include justifying the hitherto socially illegitimate exclusion of outgroups (Krämer, 2017). Framing politics in terms of friends and enemies, they constantly challenge and have eroded the boundaries of "legitimate" or acceptable political discourse and civil norms. This includes the expansion of vulgarity, fear-mongering, authoritarian aggression and ad hominem intimidation, and formerly discredited social resentments. ${ }^{19}$ Stylizing themselves as audacious "taboo-breakers" of an allegedly stifled public debate, populists often stage provocations to draw attention while pretending to be the "voice of the people" victimized by liberal media and "elite opin-

\footnotetext{
${ }^{18}$ Catering to specialized audiences, social media and websites assess preferences and encourage citizens to narrowly filter information they receive and speak only to the like-minded (Sunstein, 2009).

19 See for an analysis of these features within populist discourse Wodak (2015).
} 
ion". They frequently employ social media to "break the rules", which constitutes part of their cultural attraction (Krämer, 2017; Reinemann et al., 2017).

Not surprisingly, populist actors often praise social media for empowering the voice of the "real people" and enabling them to speak "truth" directly to the people without interference-in contrast to information from the allegedly "lying" "establishment media", in part portrayed as "enemies of the people" (D. Trump)..$^{20}$ Be that as it may, the destabilization of facticity through new digital media seems particularly beneficial to simplifications, falsehoods, and ideological binaries employed by populist actors. The culture of post-factual claims on proliferating fake news sites, which spread falsifications and invented facts and benefit from wide-spread lack of information literacy (Stanford History Education Group, 2016), undermines democratic political culture, which requires factual grounding. ${ }^{21}$ It can be theorized that the ubiquitous political relativization, inversion, and destabilization of factual truth on social media also further advances the polarization of politico-cultural conflict, insofar as truth is increasingly seen as either unrecognizable or irrelevant among groups of voters as long as claims support one's ideological cause or political convictions. This process coincides with declining trust in established news sources and mainstream media over the last two decades (Swift, 2016).

How the changed media environment specifically interacts with the rise of a populist and authoritariannativist cultural counter-revolution needs to be further theorized and studied, both in its micro-mechanisms and broader cultural impact, i.e. to determine under what specific conditions communication dynamics in digital publics broaden the cultural opportunity structures of populist politics (Koopmans \& Muis, 2009; Rensmann, 2011).

\section{Conclusion: Towards a Cultural Turn in the Study of Populist Politics}

The article has argued for a cultural turn in the study of populist politics in Europe. It proposed an ideological reconceptualization of populist actors, focusing on their long underestimated, yet constitutive cultural appeal and identity. Synthesizing, linking and integrating insights that originate in three adjacent fields - political sociology, political psychology, and media studies-we furthermore sought to advance a novel, multi-disciplinary perspective to theorize cultural conditions and dynamics at play in current trans-national populist successes.

The suggested theoretical framework conceives populist parties primarily as expressions and facilitators of a long lingering, now noisy, authoritarian-nativist cultural counter-revolution. They thrive on and mobilize a significant cultural backlash that is directed against cultural inclusion and progressive cosmopolitan social value change-as well as "others" and elites representing such change. As we have argued based on sociological empirical indicators, this counter-revolution reflects deep-seated, increasingly salient and politicized cultural conflicts about values, identities, and loyalties in European democracies: a great divide grounded in cultural and social values that largely trumps economic cleavages. The proposed theoretical framework hereby attributes a key explanatory role to the political psychology of authoritarianism-long marginalized in studies on populism-and its cultural undercurrents within European societies. The populist surge can be theorized as an authoritarian revolt forcefully expressing cultural discontent within and against modern liberal democracies. New research from media studies contributes to understanding this revolt and its transgressions as engendered by profoundly transformed communicative conditions in the digital age: they help erode standards of civil and factual discourse and benefit populist mobilizations.

To be sure, research on changed cultural conditions needs to take into account political factors that have contributed to the accelerated rise of illiberal populist actors and politics, and deserve further study. The sensed crisis of democratic legitimacy, which populist actors seek to exploit, may also be linked to mainstream parties' technocratic or failed policy responses to societal challenges (Taub, 2017). These include neo-liberal welfare state regress and widening social inequalities advanced by mainstream parties over the last two decades, inadequate attempts to develop sound, humane refugee and immigration policies, and failure to provide effective responses to political Islamism and terrorism-which do constitute real threats to citizens, denizens, and immigrants seeking civil rights and freedom in cosmopolitan immigration societies. Moreover, the reconfigured politico-cultural conflicts analyzed may have been fueled by parts of a culturalist left and radical religious groups who promote anti-cosmopolitan, illiberal politics that relativize human rights in the name of cultural identity, thus displaying affinities with identity politics of authoritarian populists.

The diagnosed noisy cultural counter-revolution mobilized by populist actors and the cultural conditions that contribute to their current success also need further, multi-disciplinarily grounded theorizing, as well as the robust operationalization and testing of hypotheses on distinct culture(s) of populism in the future. We still know too little: about the scope and origins of the salient,

\footnotetext{
${ }^{20}$ Within democracies, the Orwellian inversion in relation to news media is especially practiced by the authoritarian populist U.S. President Trump, who primarily communicates via Twitter. Attacking renowned news sources as "the Fake News Media" (in capital letters) he, emblematic also for European populists, suggests being victimized by news media: "Only the Fake News Media and Trump enemies want me to stop using social media (110 million people). Only way for me to get the truth out" (as cited in Jackson, 2017).

${ }^{21}$ Openness to processing factual information and accepting facts are arguably minimum requirements for democracy to work. Many populists and fake news sites, however, seek leveling out differences between fact, opinion, and falsehood and promote "alternative facts" (Kellyanne Conway, Counselor to the U.S. President).
} 
emotionally charged divide on socio-cultural values and identities, the grievances and conflicting forces in play, and the role of underlying socio-economic factors - such as rising economic insecurity and inequality-potentially contributing to the longing for cultural closure and value change reversal. The same applies to the emotional gratifications of what we have theorized as an authoritarian revolt, anchored in wide-spread psychological dispositions and amplified by transgressions of politico-cultural boundaries on social media. However, we believe that a better understanding of the cultural dynamics of populism will also help to assess its potential effects on the future of democracies in Europe and beyond.

\section{Acknowledgments}

The author thanks Jennet Kirkpatrick for immensely thoughtful advice, Tony Pinnell for helpful comments and edits, and the anonymous reviewers for their valuable feedback and suggestions, all of which greatly helped me clarify and substantiate my arguments and improve the final product.

\section{Conflict of Interests}

The author declares no conflicts of interest.

\section{References}

Adam, K. (2016, December 9). Anti-Islam politician Geert Wilders found guilty of discrimination. The Washington Post. Retrieved from https://www.washington post.com/world/europe/anti-islam-dutch-politicianfound-guilty-of-discrimination/2016/12/09/d651a50 a-2eb7-4efc-aeb5-be7e6727d80f_story.html?utm_ term $=.7 \mathrm{ad} 4 \mathrm{a} 223130 \mathrm{a}$

Adorno, T. W., Frenkel-Brunswik, E., Levinson, D. J., \& Sanford, R. N. (1950). The authoritarian personality. New York, NY: Harper.

Alexander, A. C., \& Welzel, C. (2017). The myth of deconsolidation: Rising liberalism and the populist reaction. Journal of Democracy. Retrieved from https://www. journalofdemocracy.org/sites/default/files/media/ Journal\%20of\%20Democracy\%20Web\%20Exchange \%20-\%20Alexander\%20and\%20Welzel.pdf

Art, D. (2011). Inside the radical right: The development of anti-immigrant parties in Western Europe. New York, NY: Cambridge University Press.

Arzheimer, K. (2009). Contextual factors and the extreme right vote in Western Europe, 1980-2002. American Journal of Political Science, 53(2), 259-275.

Betz, H. G. (2004). La droite populiste en Europe. Extrême et démocrate? [The populist right in Europe: Extreme and democratic?]. Paris: Autrement.

Bornschier, S. (2010a). The new cultural divide and the two-dimensional political space in Western Europe. West European Politics, 33(3), 419-444.

Bornschier, S. (2010b). Cleavage politics and the populist right: The new cultural conflict in Western Europe. Philadelphia, PA: Temple University Press.

Brubaker, R. (2017). Between nationalism and civilizationalism. The European populist moment in comparative perspective. Ethnic and Racial Studies, 40(8), 1191-1226.

Cannane, S. (2017, March 13). Gert Wilders pledges to 'de-Islamise' the Netherlands ahead of election. Abc News. Retrieved from http://www.abc.net.au/news/ 2017-03-13/geert-wilders-pledges-to-de-islamise-the -netherlands/8348206

Carter, E. B., \& Johnston Conover, P. (2017). For better or worse: Trump loyalists, candidate brand identification, and support. APSA. Retrieved from https:// convention2.allacademic.com/one/apsa/apsa17

Ceron, A. (2017). Social media and political accountability: Bridging the gap between citizens and politicians. Basingstoke: Palgrave Macmillan.

Chakelian, A. (2017, July 27). "It feels like a betrayal". The New Statesman. Retrieved from http://www.new statesman.com/politics/uk/2017/07/it-feels-betrayal -eu-citizens-react-jeremy-corbyn-s-migration-stance

Cohen, R. (2017, September 25). The twilight of Angela Merkel. The New York Times. Retrieved from https:// www.nytimes.com/2017/09/25/opinion/merkel-elec tion-germany-populism.html?_r=0\&mtrref=www. google.com\&gwh=80A6B999D609D79A9FABA98325 1C49AE\&gwt=pay\&assetType=opinion

Coretti, L. (2014). The purple movement: Social media and activism in Berlusconi's Italy (Doctoral thesis). University of Westminster, London, UK.

Coretti, L., \& Pica, D. (2015). The purple movement: How Facebook's design undermined the anti-Berlusconi protest in Italy. Journal of Italian Cinema \& Media Studies, 3(3), 305-318.

Dahlgren, P. (2005). The Internet, the public sphere and political communication: Dispersion and deliberation. Political Communication, 22(2), 147-162.

Damhuis, K. (2017). Wegen naar Wilders: PVV-stemmers in hun eigen woorden [Paths to Wilders: PVV voters in their own words]. Amsterdam: de Arbeiderspers.

Decker, F. (2016). The "Alternative for Germany": Factors behind its emergence and profile of a new right-wing populist party. German Politics and Society, 34(2), 1-16.

Ernst, N., Engesser, S., Büchel, F., Blassnig, S., \& Esser, F. (2017). Extreme parties and populism: An analysis of Facebook and Twitter in six countries. Information, Communication and Society, 20(9), 1347-1364.

Foa, R. S., \& Mounk, Y. (2016). The democratic disconnect. Journal of Democracy, 27(3), 5-17.

Gorondi, P. (2017, July 23). Hungary's leader: EU and Soros seek to "Muslimize" Europe. FoxNews. Retrieved from http://www.foxnews.com/world/2017/ 07/22/hungarys-leader-border-fences-will-stop-mus lim-migration.html

Greven, T. (2016). The rise of right-wing populism in Europe and the United States: A comparative perspec- 
tive. Washington, DC: Friedrich Ebert Foundation.

Guiso, L., Herrera, H., \& Morelli, M. (2017). Demand and suply of populism (Center for Economic Policy Research Discussion Paper). London: CEPR.

Haaretz (2017, July 19). Far left French leader slams Macron for accepting French complicity in Holocaust. Haaretz. Retrieved from http://www.haaretz. com/world-news/europe/1.802131

Hartleb, F. (2017). Die Stunde der Populisten [The hour of the populists]. Frankfurt: Wochenschau Verlag.

Hetherington, M. J., \& Weiler, J. D. (2009). Authoritarianism and polarization in American politics. New York, NY: Cambridge University Press.

Hirsh, D. (2017). Contemporary left antisemitism. New York, NY: Routledge.

Ignazi, P. (1992). The silent counter-revolution. Hypotheses on the emergence of extreme right parties in Europe. European Journal for Political Research, 22(1), 3-34.

Ignazi, P. (2003). Extreme right parties in Western Europe. Oxford: Oxford University Press.

Inglehart, R. (1977). The silent revolution. Changing values and political styles among Western publics. Princeton, NJ: Princeton University Press.

Inglehart, R., \& Norris, P. (2009). Cosmopolitan communications: Cultural diversity in a globalized world. New York, NY: Cambridge University Press.

Inglehart, R., \& Norris, P. (2016). Trump, Brexit, and the rise of populism: Economic have-nots and cultural backlash (Harvard Faculty Research Working Papers). Cambridge, MA: Harvard University.

Inglehart, R., \& Welzel, C. (2005). Modernization, cultural change, and democracy. New York, NY: Cambridge University Press.

Jackson, D. (2017, August 1). After swearing in new chief of staff, Trump pledges: I won't stop tweeting. USA Today. Retrieved from https://www.usatoday.com/ story/news/politics/onpolitics/2017/08/01/after-hir ing-new-chief-staff-trump-pledges-keep-tweeting/ 528553001

Johnson, A. (2017, March 28). Why Brexit is best for Britain: The left-wing case. The New York Times. Retrieved from https://www.nytimes.com/2017/03/ 28/opinion/why-brexit-is-best-for-britain-the-left-wing -case.html

Kaldor, M. (1997). Cosmopolitanism versus nationalism: The new divide? In R. Caplan \& J. Feffer (Eds.), Europe's new nationalism (pp. 42-58). Oxford: Oxford University Press.

Kentish, B. (2017, May 7). Nearly half of young French voters backed Marine Le Pen. The Independent. Retrieved from http://www.independent.co.uk/news/ nearly-half-young-french-voters-marine-le-pen-emma nuel-macron-french-election-2017-a7723291.html

Koopmans, R., \& Muis, J. (2009). The rise of right-wing populist Pim Fortuyn in the Netherlands: A discursive opportunity approach. European Journal of Political Research, 48(5), 642-664.
Krämer, B. (2017). Populist online practices: The function of the Internet in right-wing populism. Information, Communication and Society, 20(9), 1293-1309.

Kriesi, H., Grande, E, Lachat, M. R., Dolezal, M., Bornshier, S., \& Frey, T. (2006). Globalization and the transformation of the national political space: Six European countries compared. European Journal of Political Research, 45(6), 921-956.

Kriesi, H. (2014). The populist challenge. West European Politics, 37(2), 361-378.

Les Echos. (2015, March 24). Les partis de gouvernement ont perdu l'électorat populaire: En savoir plus sur [Government parties have lost the popular electorate: Learn more about it]. Les Echos. Retrieved from https://www.lesechos.fr/24/03/2015/LesEchos /21904-016-ECH_les-partis-de-gouvernement-ont-per du-I-electorat-populaire.htm

MacWilliams, M. (2016, January 17). The one weird trait that predicts whether you're a Trump supporter. Politico. Retrieved from http://www.politico.com/ magazine/story/2016/01/donald-trump-2016-author itarian-213533

Mazzoleni, G. (2008). Populism and the media. In D. Albertazzi \& D. McDonnell (Eds.), Twenty-first century populism (pp. 49-64). Basingstoke: Palgrave Macmillan.

Moffitt, B., \& Tormey, S. (2014). Rethinking populism: Politics, mediatisation and political style. Political Studies, 62(2), 381-397.

Mudde, C. (2005). The populist zeitgeist. Government \& Opposition, 39(4), 541-563.

Mudde, C. (2007). Populist radical right parties in Europe. Cambridge: Cambridge University Press.

Mudde, C. (2013). Three decades of populist radical right parties in Western Europe: So what? European Journal of Political Research, 52(1), 1-19.

Mudde, C., \& Rovira Kaltwasser, C. (2013). Exclusionary vs. inclusionary populism: Comparing contemporary Europe and Latin America. Government and Opposition, 48(2), 147-174.

Mudde, C., \& Rovira Kaltwasser, C. (2017). Populism: A very short introduction. New York, NY: Oxford University Press.

Muis, J., \& Immerzeel, T. (2017, July 14). Causes and consequences of the rise of populist radical right parties and movements in Europe. Current Sociology, 65(6), 909-930.

Müller, J. W. (2016). What is populism? Philadelphia, PA: University of Pennsylvania Press.

Nauman, F. (2017, September 25). Fast 13 Prozent bei der Bundestagswahl: Wer hat die AfD gewählt? [Almost 13 percent at the national parliamentary election: Who voted for the AfD?]. Merkur.de. Retrieved from https://www.merkur.de/politik/wer-hat-afd-ge waehlt-fast-13-prozent-bei-bundestagswahl-2017-zr8715057.html

Norris, P. (2017). Is Western democracy backsliding? Diagnosing the risks. Journal of Democracy. Re- 
trieved from https://www.journalofdemocracy.org/ sites/default/files/media/Journal\%20of\%20Democra cy\%20Web\%20Exchange\%20-\%20Norris_0.pdf

Osel, J. (2017, September 28). Wie die AfD im schwarzen Stammland siegte [How the AfD won in the conservative homeland]. Süddeutsche Zeitung. Retrieved from http://www.sueddeutsche.de/bayern/ deggendorf-wie-die-afd-im-schwarzen-stammlandsiegte-1.3685840

Ostrand, N. (2017). The Syrian refugee crisis: A comparison of response by Germany, Sweden, the United Kingdom, and the United States. Journal on Migration and Human Security, 3(3), 255-279.

Pettigrew, T. F. (2017). Social psychological perspectives on Trump supporters. Journal of Social and Political Psychology, 5(1), 107-116.

Poushter, J. (2016). European opinion of the refugee crisis in 5 charts. PEW Research Center. Retrieved from http://www.pewresearch.org/fact-tank/2016/ 09/16/european-opinions-of-the-refugee-crisis-in-5charts

Reinemann, C., Aalberg, T., Esser, F., Strömbäck, J., \& de Vreese, C. H. (2017). Populist political communication: Towards a model of its causes, forms and effects. In T. Aalberg, F. Esser, C. Reinemann, J. Strömbäck, \& C. H. De Vreese (Eds.), Populist political communication in Europe (pp. 12-25). New York, NY: Routledge.

Rensmann, L. (2006). Populismus und Ideologie [Populism and ideology]. In F. Decker (Ed.), Populismus: Gefahr für die Demokratie oder nützliches Korrektiv? [Populism: Danger for democracy or useful corrective?] (pp. 59-80). Wiesbaden: VS Verlag für Sozialwissenschaften.

Rensmann, L. (2011). Against 'globalism': Antisemitism and counter-cosmopolitanism in the party ideology of the extreme right in Europe. In L. Rensmann \& J. H. Schoeps (Eds.), Politics and resentment: Countercosmopolitanism and antisemitism in the European Union (pp. 117-146). Boston, MA: Brill.

Rensmann, L. (2012). Volatile counter-cosmopolitans: Understanding the electoral performance of radical right parties in Eastern Germany and Poland. German Politics and Society, 30(2), 64-102.

Rensmann, L. (2014). The reluctant cosmopolitanization of European party politics: The case of Germany. German Politics and Society, 32(2), 59-85.

Rensmann, L. (2017). The politics of unreason. Albany, NY: SUNY Press.

Rooduijn, M. (2014). Vox populismus: A populist radical right attitude among the public? Nations and Nationalism, 20(1), 80-92.

Röpcke, J. (2017, September 24). Russen-accounts pushen AfD-Kamapagne [Russian accounts push AfD campaign]. Bild. Retrieved from http://www.bild.de/ politik/inland/bundestagswahl2017/russen-bot-netz -verbreitet-afd-propaganda-53313520.bild.html
Rotella, S. (2017, April 20). France's elections are just the latest in Russia's shadow war in a wary Europe. Salon. Retrieved from https://www.salon.com/2017/ 04/20/russias-shadow-war-in-a-wary-europe_partner

Shane, S. (2017, September 7). The fake Americans Russia created to influence the election. The New York Times. Retrieved from https://www.nytimes.com/ 2017/09/07/us/politics/russia-facebook-twitter-elec tion.html?mcubz=3

Sniderman, P. M., \& Hagendoorn, L. (2007). When ways of life collide: Multiculturalism and its discontents in the Netherlands. Princeton, NJ: Princeton University Press.

Stanford History Education Group. (2016). Evaluating information: The cornerstone of civic online reading. Stanford University. Retrieved from https://sheg. stanford.edu/upload/V3LessonPlans/Executive\%20 Summary\%2011.21.16.pdf

Sunstein, C. R. (2009). Republic.com 2.0. Princeton, NJ: Princeton University Press.

Swift, A. (2016, September 14). Americans' trust in mass media sinks to new low. Gallup. Retrieved from http://www.gallup.com/poll/195542/ americans-trust-mass-media-sinks-new-low.aspx

Taub, A. (2017, September 26). What the far right may mean for Germany's future. The New York Times. Retrieved from https://www.nytimes.com/2017/09/ 26/world/europe/germany-far-right-election.html

Teperoglou, E., \& Tsatsanis, E. (2011). A new divide? The impact of globalization on national party systems. West European Politics, 34(6), 1207-1228.

Treré, E., \& Barassi, V. (2015). Net-authoritarianism? How web ideologies reinforce political hierarchies in the Italian 5 Star Movement. Journal of Italian Cinema \& Media Studies, 3(3), 287-304.

Trump, D. J. (2017, January 20), The inaugural address. The White House. Retrieved from https://www. whitehouse.gov/inaugural-address

Voeten, E. (2017). Are people really turning away from democracy? Journal of Democracy. Retrieved from http://journalofdemocracy.org/sites/default/files/ media/Journal\%20of\%20Democracy\%20Web\%20Ex change\%20-\%20Voeten_0.pdf

Wirth, W., Esser, F., Wettstein, M., Engesser, S., Wirz, D., Schulz, A., . . Müller, P. (2016). The appeal of populist ideas, strategies and styles: A theoretical model and research design for analyzing populist political communication (National Centre of Competence in Research (NCCR) Working Paper no.88): Zurich: University of Zurich.

Wodak, R. (2015). The politics of fear: What right-wing populist discourses mean. London: Sage.

Zúquete, J. P. (2008). The European extreme-right and Islam: New directions? Journal of Political Ideologies, 13(3), 321-344. 


\section{About the Author}

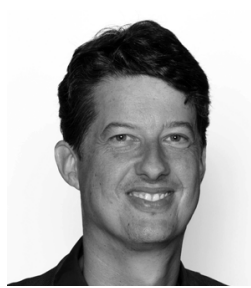

Lars Rensmann is Professor of European Politics and Society at the Centre of International Relations and Chair of the Department of European Languages and Cultures at the University of Groningen. He has published many journal articles and several books on European and global politics; European political theory; populism, antisemitism, and the radical right in Europe; and global politics and sports. His most recent book The Politics of Unreason: The Frankfurt School and the Origins of Modern Antisemitism was published by State University of New York Press in 2017. 